\title{
Coexpression of IL-6 and TNF-a: prognostic significance on breast cancer outcome
}

\author{
G. TRIPSIANIS ${ }^{1, *}$, E. PAPADOPOULOU ${ }^{2}$, K. ANAGNOSTOPOULOS ${ }^{2}$, S. BOTAITIS ${ }^{3}$, M. KATOTOMICHELAKIS ${ }^{4}$, K. ROMANIDIS ${ }^{3}$, \\ E. KONTOMANOLIS 5 , I. TENTES ${ }^{2}$, A. KORTSARIS ${ }^{2}$
}

${ }^{1}$ Laboratory of Medical Statistics, Medical School, Democritus University of Thrace, 68100 Alexandroupolis, Greece; ${ }^{2}$ Laboratory of Biochemistry, Medical School, Democritus University of Thrace, Alexandroupolis, Greece; ${ }^{3}$ Second Department of Surgery, Medical School, Democritus University of Thrace, Alexandroupolis, Greece; ${ }^{4}$ Department of Otorhinolaryngology, Medical School, Democritus University of Thrace, Alexandroupolis, Greece; ${ }^{5}$ Department of Obstetrics and Gynecology, Medical School, Democritus University of Thrace, Alexandroupolis, Greece

*Correspondecne: gtryps@med.duth.gr

Received May 25, 2013 / Accepted June 26, 2013

\begin{abstract}
Presented study was conducted to investigate the prognostic significance of the coexpression of serum interleukin-6 (IL-6) and tumor necrosis factor-a (TNF-a) in breast cancer, by correlating their presence with clinicopathological characteristics indicative of tumor progression and the overall survival of breast cancer patients. One hundred twelve consecutive patients with primary breast cancer were prospectively included and evaluated. Serum concentrations of IL- 6 and TNF-a were measured by quantitative sandwich enzyme immunoassay (ELISA). Median split was used to subdivide patients with low or high IL-6 and TNF-a levels. A positive association between the expression of the two cytokines was found. The coexpression of high IL-6 and TNF- $\alpha$ was independently associated with extended lymph node (>3) involvement (aOR, 7.8) and lymphovascular invasion (aOR, 14.1), increasing the prognostic significance of each cytokine separately; it also provided additional prognostic information regarding survival, defining a high-risk subgroup of patients with significantly shorter survival and higher risk of death compared to patients with both cytokines low (aHR, 4.45) and patients with only one cytokine high (aHR, 3.63). Our findings suggest that the coexpression of these two cytokines could be used clinically as a useful tumor marker for the extension and the outcome of the disease.
\end{abstract}

Key words: IL-6, TNF- $\alpha$, breast cancer, prognosis, metastasis, survival

Breast cancer is the most common malignancy in women. Its aetiology is multifactorial, the period of development can span decades and clinical course is highly variable. Tumor markers for breast cancer include pathologic characteristics, such as tumor size, tumor grade, and lymph node status [1], as well as biological factors such as hormone receptors, HER-2, urokinase plasminogen activator, and plasminogen activator inhibitor $1[2,3]$, may help in the initial assessment of the extent of the disease and the prediction of response or resistance to specific therapies. All of these factors require tumor tissue, thus necessitating either biopsy or surgery. It would be desirable to have a serum prognostic marker for breast cancer, particularly if it provided independent prognostic information. Although, for many malignancies, serum tumor markers play an important role in patient management [4-8], in breast cancer the role of serum markers is less well established [9].
Serum markers, such as CA 15-3, carcinoembryonic antigen (CEA) and the shed form of HER-2, have been widely investigated for potential prognostic value in breast cancer $[9,10]$, but their independent impact on determining prognosis was not established in several large scale studies [11-13].

One approach in the exploration into the mechanisms related to the occurrence, invasion and metastasis of breast cancer is the evaluation of serum cytokines and cytokine receptors, which play regulatory roles in disease development. Cytokines are pleiotropic molecules who share common characteristics including a) they are biologically active at low concentrations, b) they exert their biological effects by binding and signaling through cell surface receptors, and c) they can be additive, synergistic, or antagonistic [14]. Since changes in cytokine levels mediated by the tumor both directly and indirectly are important parameters that affect the course of 
disease, they have received a great deal of attention by many researchers as potential diagnostic and prognostic markers in breast cancer $[15,16]$.

One important cytokine in breast cancer is IL-6, a proinflammatory cytokine involved in various other physiological and pathological processes in the body. IL-6 is produced by macrophages, B-cells, T-cells, endothelial cells, osteoblasts [17] and tumor cells [18] and is active in the immune response, haematopoiesis, the acute phase response and inflammation. IL-6 can also act as an autocrine or paracrine cancer cell growth factor and contribute to recurrence and metastasis in breast cancer. TNF-a, another extremely pleiotropic cytokine, is produced by a wide range of pathogenic stimuli, such as macrophages, neutrophiles, fibroblasts, NK cells, astrocytes, $\mathrm{T}$ and $\mathrm{B}$ cells, Kupffer cells, smooth muscle cells and keratinocytes; TNF-a is also produced by tumor cells and can act as an endogenous tumor promoter [19-21]. TNF-a has been shown to be one of the major mediators of inflammation [21] and it is also able to affect the expression of growth factors and other cytokines, via multiple signal transduction pathways [22].

There is increasing evidence that serum levels of IL- 6 and TNF-a reflect tumor maintenance and aggressiveness in breast cancer patients. In two previous papers, based on a smaller cohort, we have shown that serum levels of IL- 6 and TNF-a were independent prognostic markers of breast cancer outcome and survival $[23,24]$. Despite the generally good outcome of each cytokine, it is well understood that multiple marker investigation rather than a single tumor marker would be of benefit towards on defining better prognostic biomarkers that would allow a more precise strategy of treatment based upon the subgrouping of patients. Therefore, in the present study, we examine the prognostic value of the coexpression pattern of serum levels of IL- 6 and TNF-a, by evaluating the association of their presence with the clinicopathological characteristics indicative of tumor progression and the overall survival of breast cancer patients.

\section{Materials and methods}

Study population. One hundred twelve consecutive patients with primary breast carcinoma, admitted to the University General Hospital of Alexandroupolis were included in the presented population-based study. The diagnosis of breast cancer was confirmed by histological examination, using specimens obtained from biopsy or surgical resection. Tumors were graded according to the criteria described by Bloom and Richardson [25] and tumor stage was assigned according to the TNM classification defined by the Union International Against Cancer [26]. The expressions of estrogen receptor (ER), progesterone receptor (PR) and HER-2 proteins were considered positive if $10 \%$ of the cancer cells showed immunoreactivity. Forty five healthy females with no evidence of neoplastic disease, who visited our hospital for routine health checkup, frequency matched to breast cancer patients based upon age, were recruited as controls. Written informed consent was obtained from all women and the Regional ethical committee approved the study.

Measurement of serum IL- 6 and TNF- $\alpha$. Peripheral blood samples were collected from each patient before operation. After centrifugation at $3000 \mathrm{rpm}$ for $20 \mathrm{~min}$, serum samples were frozen and stored at $-70{ }^{\circ} \mathrm{C}$ until biochemical assessment. Quantitative sandwich enzyme immunoassay (ELISA) was performed for measuring concentrations of serum IL-6 and TNF- $\alpha$, by means of a commercially available kit (ImmunoKontact, AMS Biotechnology, U.K.).

Statistical analysis. Statistical analysis of the data was performed using the Statistical Package for the Social Sciences (SPSS), version 19.0 (IBM). The normality of IL-6 and TNF- $\alpha$ levels was tested with Kolmogorov-Smirnov test. Both cytokines were expressed as the median and interquartile range (IQR; $25^{\text {th }}$ to $75^{\text {th }}$ percentile). Mann-Whitney U test test was used to assess differences of IL- 6 and TNF- $\alpha$ levels between patients and controls. In the sequence, median split was used to subdivide patients into groups with low or high IL- 6 and TNF- $\alpha$ levels. The chi-square test was used to assess the association of IL- 6 and TNF- $\alpha$ expression with patients' characteristics. Multivariate stepwise logistic regression analysis was constructed to explore the independent effect of clinicopathological parameters on IL- 6 and TNF- $\alpha$ expression. Odds ratios (OR) and their 95\% confidence intervals (CI) were estimated as the measure of association of cytokines expression with patients' characteristics. As indicator of survival the disease-specific survival (including only death related to the disease as an event) was investigated. Survival rates were calculated with the Kaplan-Meier method and the statistical difference between survival curves was determined with the log-rank test. Multivariate Cox proportional hazards regression analysis, using a backward selection approach, were performed to explore the independent effect of cytokines and clinicopathological parameters on overall survival. All tests were two tailed and statistical significance was considered for $\mathrm{p}$ values $<0.05$.

\section{Results}

Characteristics of study population. The study population was consisted of 112 breast cancer patients with a median age of 65 years (range, 33 - 84 years; mean age $\pm \mathrm{SD}, 63.41 \pm 12.00$ years). The clinicopathological characteristics of the tumors are shown in Table 1. Regarding to histology, 90 (83.4\%) were ductal and 22 (19.6\%) lobular carcinomas. More than $80 \%$ of cases were invasive carcinomas (93 patients, $83.0 \%$ ) and the majority of the tumors had size between 2 and $5 \mathrm{~cm}$ (T2; 72 patients, 64.3\%). Nineteen (17.0\%) were well-differentiated (G1), 18 (16.0\%) were moderately differentiated (G2) and 75 (67.0\%) were poorly differentiated carcinomas. Half of the cases (56 patients, $50.0 \%)$ were of stage II, while in 53 patients (47.3\%) lymph node metastases were detected; in 46 of them (49.1\%) the number of positive lymph nodes was greater than three. ER, 
PR and HER-2 positivity was detected in $69.6 \%, 42.9 \%$ and $54.5 \%$ of the patients, respectively.

Association of IL-6 \& TNF- $\alpha$ with clinicopathological parameters. Patients with primary breast cancer exchibited significantly higher levels of serum IL-6 (median (IQR), 6.81 $\mathrm{pg} / \mathrm{ml}(5.24-10.19 \mathrm{pg} / \mathrm{ml})$ vs $1.49 \mathrm{pg} / \mathrm{ml}(0.85-2.69 \mathrm{pg} / \mathrm{ml})$, $\mathrm{p}<0.001)$ and TNF- $\alpha(18.93 \mathrm{pg} / \mathrm{ml}(12.01-30.26 \mathrm{pg} / \mathrm{ml}) \mathrm{vs}$ $7.92 \mathrm{pg} / \mathrm{ml}(4.41-12.14 \mathrm{pg} / \mathrm{ml}), \mathrm{p}<0.001)$ compared to the control group. In order to assess the relation of IL- 6 and TNF- $\alpha$ with the clinicopathological parameters and overall survival, the patients' median values were selected as the cut-off points to subdivide breast cancer patients into (i) patients with low or high IL-6 (if IL-6 was $<6.81 \mathrm{pg} / \mathrm{ml}$ or $\geq 6.81$ $\mathrm{pg} / \mathrm{ml}$, respectively) and (ii) patients with low or high TNF- $\alpha$ (if TNF- $\alpha$ was $<18.93 \mathrm{pg} / \mathrm{ml}$ or $\geq 18.93 \mathrm{pg} / \mathrm{ml}$, respectively). The presence of high IL- 6 and TNF-a levels was analyzed in relation to the following parameters: patient's age, histological type, lymphovascular invasion, tumor size, histological grade,

Table 1. Characteristics of breast cancer patients

\begin{tabular}{|c|c|c|}
\hline & No of patients & Percentage (\%) \\
\hline \multicolumn{3}{|l|}{ Age } \\
\hline$\leq 45$ years & 14 & 12.5 \\
\hline $46-65$ years & 48 & 42.9 \\
\hline$>65$ years & 50 & 44.6 \\
\hline \multicolumn{3}{|l|}{ Histological type } \\
\hline Lobular & 22 & 19.6 \\
\hline Ductal & 90 & 80.4 \\
\hline \multicolumn{3}{|c|}{ Lymphovascular invasion } \\
\hline No & 19 & 17.0 \\
\hline Yes & 93 & 83.0 \\
\hline \multicolumn{3}{|l|}{ Tumor size } \\
\hline $\mathrm{T} 1$ & 33 & 29.5 \\
\hline $\mathrm{T} 2$ & 72 & 64.3 \\
\hline $\mathrm{T} 3$ & 7 & 6.2 \\
\hline \multicolumn{3}{|l|}{ Histological grade } \\
\hline G1 & 19 & 17.0 \\
\hline G2 & 18 & 16.0 \\
\hline G3 & 75 & 67.0 \\
\hline \multicolumn{3}{|l|}{ Clinical stage } \\
\hline $0-\mathrm{I}$ & 30 & 26.8 \\
\hline II & 56 & 50.0 \\
\hline III-IV & 26 & 23.2 \\
\hline \multicolumn{3}{|l|}{ Lymph node status } \\
\hline Negative & 59 & 52.7 \\
\hline Positive & 53 & 47.3 \\
\hline \multicolumn{3}{|c|}{ No of positive lymph nodes } \\
\hline$\leq 3$ lymph nodes & 27 & 50.9 \\
\hline$>3$ lymph nodes & 26 & 49.1 \\
\hline \multicolumn{3}{|l|}{ Estrogen receptors } \\
\hline Negative & 34 & 30.4 \\
\hline Positive & 78 & 69.6 \\
\hline \multicolumn{3}{|l|}{ Progesterone receptors } \\
\hline Negative & 64 & 57.1 \\
\hline Positive & 48 & 42.9 \\
\hline \multicolumn{3}{|l|}{ HER-2 protein } \\
\hline Negative & 51 & 45.5 \\
\hline Positive & 61 & 54.5 \\
\hline
\end{tabular}

clinical stage, lymph node status, number of positive lymph nodes and the immunohistochemical expression of ER, PR and HER-2 (Table 2). The presence of high IL-6 levels was significantly associated with ages older than 65 years $(\mathrm{cOR}=8.7$, 95\% C.I. $=3.7-20.6, \mathrm{p}<0.001)$, invasive tumors $(\mathrm{cOR}=3.6,95 \%$ C.I. $=1.2-10.7, p=0.019)$, advanced stages $(\mathrm{cOR}=2.7,95 \%$ C.I. $=1.1-6.9, \mathrm{p}=0.033)$, the presence of more than three positive lymph nodes (cOR=5.7, 95\% C.I. $=1.7-18.8, \mathrm{p}=0,003$ ), the immunohistochemical over-expression of $\mathrm{ER}(\mathrm{cOR}=3.6,95 \%$ C.I. $=1.5-8.7, \mathrm{p}=0.003)$ and HER-2 $(\mathrm{cOR}=2.8,95 \%$ C.I. $=1.3-$ $6.0, \mathrm{p}=0.008)$. Furthermore, the presence of high TNF-a levels was more frequent in invasive tumors ( $\mathrm{cOR}=2.5,95 \%$ C.I. $=0.9-7.2, \mathrm{p}=0.078)$, poorly differentiated tumors $(\mathrm{cOR}=3.0$, 95\% C.I. $=1.3-6.8, \mathrm{p}=0.009)$, advanced stages $(\mathrm{cOR}=2.8,95 \%$ C.I. $=1.1-7.2, \mathrm{p}=0.025)$ and in patients with more than three positive lymph nodes ( $\mathrm{cOR}=4.5,95 \%$ C.I. $=1.4-14.3, \mathrm{p}=0.009)$. Multivariate stepwise logistic regression analysis revealed that the presence of more than three positive lymph nodes

Table 2. High levels of IL-6 and TNF-a in patients with breast cancer according to clinicopathological parameters. Data are expressed as frequencies and percentages.

\begin{tabular}{|c|c|c|c|c|}
\hline & High IL-6 & $\mathrm{p}$ value & High TNF-a & $\mathrm{p}$ value \\
\hline Age & & $<0.001$ & & 0.705 \\
\hline$\leq 45$ years & $3(21.4)$ & & $8(57.1)$ & \\
\hline $45-65$ years & $15(31.3)$ & & $22(45.8)$ & \\
\hline$>65$ years & $39(78.0)$ & & $26(52.0)$ & \\
\hline Histological type & & 0.926 & & 0.341 \\
\hline Lobular & $11(50.0)$ & & $13(59.1)$ & \\
\hline Ductal & $46(51.1)$ & & $43(47.8)$ & \\
\hline Lymphovascular invasion & & 0.019 & & 0.078 \\
\hline No & $5(26.3)$ & & $6(31.6)$ & \\
\hline Yes & $52(55.9)$ & & $50(53.8)$ & \\
\hline Tumor size & & 0.617 & & 0.300 \\
\hline T1 & $18(54.5)$ & & $19(57.6)$ & \\
\hline $\mathrm{T} 2-\mathrm{T} 3$ & $39(49.4)$ & & $37(46.8)$ & \\
\hline Histological grade & & 0.255 & & 0.009 \\
\hline G1 - G2 & $16(43.2)$ & & $12(32.4)$ & \\
\hline G3 & $41(54.7)$ & & $44(58.7)$ & \\
\hline Clinical stage & & 0.033 & & 0.025 \\
\hline I-II & $39(45.3)$ & & $38(44.2)$ & \\
\hline III-IV & $18(69.2)$ & & $18(69.2)$ & \\
\hline Lymph node status & & 0.252 & & 0.850 \\
\hline Negative & $27(45.8)$ & & $29(49.2)$ & \\
\hline Positive & $30(56.6)$ & & $27(50.9)$ & \\
\hline No of positive lymph nodes & & 0.003 & & 0.009 \\
\hline$\leq 3$ lymph nodes & $10(37.0)$ & & $9(33.3)$ & \\
\hline$>3$ lymph nodes & $20(76.9)$ & & $18(69.2)$ & \\
\hline Estrogen receptors & & 0.048 & & 0.411 \\
\hline Negative & $10(29.4)$ & & $19(55.9)$ & \\
\hline Positive & $47(60.3)$ & & $37(47.4)$ & \\
\hline Progesterone receptors & & 0.173 & & 0.127 \\
\hline Negative & $29(45.3)$ & & $36(56.3)$ & \\
\hline Positive & $28(58.3)$ & & $20(41.7)$ & \\
\hline HER-2 protein & & 0.008 & & 0.343 \\
\hline Negative & $19(37.3)$ & & $23(45.1)$ & \\
\hline Positive & $38(62.3)$ & & $33(54.1)$ & \\
\hline
\end{tabular}


$(\mathrm{aOR}=4.2,95 \%$ C.I. $=1.2-14.3, \mathrm{p}=0.024)$ and invasive tumors $(\mathrm{aOR}=2.7$, 95\% C.I. $=1.2-6.1, \mathrm{p}=0.019)$ remained significant independent determinants of high levels of IL-6, while poorly differentiated tumors $(\mathrm{aOR}=3.5,95 \%$ C.I. $=1.4-8.7, \mathrm{p}=0.008)$ and the presence of more than three positive lymph nodes $(\mathrm{aOR}=3.8,95 \%$ C.I. $=1.2-11.9, \mathrm{p}=0.019)$ were significant independent determinants of high levels of TNF-a in breast cancer patients.

The coexpression of IL- 6 and TNF-a in relation to the clinicopathological parameters was examined next (Table 3). In almost $70 \%$ of the patients the same expression of the two cytokines was detected (both low in 33.\% and both high in $33.9 \%)$; high expression of TNF-a was more frequent among high IL- 6 patients than among low IL- 6 patients $(67.9 \%$ vs $32.1 \%, \mathrm{p}<0.001$; Spearman's $\rho=0.373, \mathrm{p}<0.001$ for the quantitive expression of the two cytokines). The coexpression of the two cytokines was significantly associated with patients' age $(p=0.019)$, lymphovascular invasion $(p=0.015)$, clinical stage $(\mathrm{p}=0.007)$, the number of positive lymph nodes $(\mathrm{p}<0,001)$, the immunohistochemical expression of HER-2 $(p=0.046)$ and histological grade (0.072). In particular, the simultaneous expression of high IL- 6 and TNF-a levels was more likely to be found in ages $>65$ years $(\mathrm{cOR}=3.8,95 \%$ C.I. $=1.7-8.6, \mathrm{p}=0.001)$, invasive tumors $(\mathrm{cOR}=11.9,95 \%$ C.I. $=1.5-92.9, \mathrm{p}=0.004)$, poorly differentiated tumors $(\mathrm{cOR}=2.4,95 \%$ C.I. $=1.0-6.0$, $\mathrm{p}=0.053)$ and in patients with more than three positive lymph nodes $(\mathrm{cOR}=5.1,95 \%$ C.I. $=1.5-17.7, \mathrm{p}=0.007)$; invasive tumors $(\mathrm{aOR}=14.1,95 \%$ C.I. $=1.6-122.0, \mathrm{p}=0.016)$ and the presence of more than three positive lymph nodes $(\mathrm{aOR}=7.8,95 \%$ C.I. $=2.1-29.5, \mathrm{p}=0.001)$ remained significant independent determinants of the simultaneous presence of high IL-6 and TNF-a levels.

Association of IL-6 \& TNF- $\boldsymbol{\alpha}$ with survival. After a median follow up period of 30 months (range, 3-68 months), 24 (21.4\%) patients died as a consequence of disease progression. Among the entire cohort, the mean survival time was

Table 3. Co-expression of IL-6 and TNF-a in breast cancer patients in relation to their clinicopathological parameters. Data are expressed as frequencies and percentages.

\begin{tabular}{|c|c|c|c|c|}
\hline & \multicolumn{3}{|c|}{ Coexpression of IL- 6 \& TNF-a } & \multirow[b]{2}{*}{$\mathrm{p}$ value } \\
\hline & IL-6 and TNF-a low & IL- 6 or TNF-a high & IL-6 and TNF-a high & \\
\hline Age & & & & 0.019 \\
\hline$\leq 45$ years & $6(42.9)$ & $5(35.7)$ & $3(21.4)$ & \\
\hline $45-65$ years & $21(43.8)$ & $17(35.4)$ & $10(20.8)$ & \\
\hline$>65$ years & $10(20.0)$ & $15(30.0)$ & $25(50.0)$ & \\
\hline Histological type & & & & 0.224 \\
\hline Lobular & $8(36.4)$ & $4(18.2)$ & $10(45.4)$ & \\
\hline Ductal & $29(32.2)$ & $33(36.7)$ & $28(31.1)$ & \\
\hline Lymphovascular invasion & & & & 0.015 \\
\hline No & $9(47.4)$ & $9(47.4)$ & $1(5.3)$ & \\
\hline Yes & $28(30.1)$ & $28(30.1)$ & $37(39.8)$ & \\
\hline Tumor size & & & & 0.643 \\
\hline $\mathrm{T} 1$ & $9(27.3)$ & $11(33.3)$ & $13(39.4)$ & \\
\hline $\mathrm{T} 2-\mathrm{T} 3$ & $28(35.4)$ & $26(32.9)$ & $25(31.6)$ & \\
\hline Histological grade & & & & 0.072 \\
\hline I-II & $17(45.9)$ & $12(32.4)$ & $8(21.6)$ & \\
\hline III & $20(26.7)$ & $25(33.3)$ & $30(40.0)$ & \\
\hline Clinical stage & & & & 0.007 \\
\hline I-II & $35(40.7)$ & $25(29.1)$ & $26(30.2)$ & \\
\hline III-IV & $2(7.7)$ & $12(46.2)$ & $12(46.2)$ & \\
\hline Lymph node status & & & & 0.597 \\
\hline Negative & $22(37.3)$ & $18(30.5)$ & $19(32.2)$ & \\
\hline Positive & $15(28.3)$ & $19(35.8)$ & $19(35.8)$ & \\
\hline Positive lymph nodes & & & & $<0.001$ \\
\hline$\leq 3$ lymph nodes & $15(55.6)$ & $7(25.9)$ & $5(18.5)$ & \\
\hline$>3$ lymph nodes & - & $12(46.2)$ & $14(53.8)$ & \\
\hline Estrogen receptors & & & & 0.409 \\
\hline Negative & $14(41.2)$ & $11(32.4)$ & $9(26.5)$ & \\
\hline Positive & $23(29.5)$ & $26(33.3)$ & $29(37.2)$ & \\
\hline Progesterone receptors & & & & 0.748 \\
\hline Negative & $20(31.3)$ & $23(35.9)$ & $21(32.8)$ & \\
\hline Positive & $17(35.4)$ & $14(29.2)$ & $17(35.4)$ & \\
\hline HER-2 protein & & & & 0.046 \\
\hline Negative & $23(45.1)$ & $14(27.5)$ & $14(27.5)$ & \\
\hline Positive & $14(23.0)$ & $23(37.7)$ & $24(39.3)$ & \\
\hline
\end{tabular}


$55 \pm 2$ months (95\% C.I. $=51-60$ months; median survival time was not reached). Mean survival time was $61 \pm 2$ months (95\% C.I. $=56-66$ months) in patients with low levels of IL-6 and $40 \pm 3$ months ( $95 \%$ C.I. $=35-45$ months) in patients with high levels of IL-6. In addition, mean survival time was $60 \pm 3$ months (95\% C.I. $=55-65$ months) in patients with low levels of TNF-a and $45 \pm 3$ months (95\% C.I. $=39-51$ months) in patients with high levels of TNF-a. The log-rank test revealed statistically significant differences between survival rates over time (IL-6: $p=0.008$; TNF-a: $p=0.010$ ), with patients with high levels of IL-6 or TNF-a having worse prognosis. The incidence of death was significantly higher in patients with high IL-6 than in patients with low IL-6 (29.8\% vs. $12.7 \%, \mathrm{p}=0.027$; Hazard ratio $(\mathrm{HR})=3.14$, 95\% C.I. $=1.30$ 7.65), and in patients with high TNF-a than in patients with low TNF-a (30.4\% vs. $12.5 \%, \mathrm{p}=0.021 ; \mathrm{HR}=3.04,95 \%$ C.I. $=1.25-7.36)$.

In the sequence, we defined the following three groups according to the co-expression of the two herein studied cytokines: group A (patients with both IL-6 and TNF-a low), group B (patients with IL-6 or TNF-a high) and group C (patients with both IL-6 and TNF-a high). Survival analysis in relation to IL-6 and TNF-a co-expression showed that the 1,2 and 3-year survival of patients of group A was $97.30 \pm 2.67 \%, 94.05 \pm 4.10 \%$ and $90.44 \pm 5.30 \%$, whereas the respective percentages for group B were $97.06 \pm 2.90 \%$, $87.40 \pm 5.32 \%$ and $78.95 \pm 8.83 \%$ and for group C were $89.47 \pm 4.78 \%, 68.72 \pm 7.13 \%, 52.49 \pm 9.36 \%$. Furthermore, the mean survival time was $62 \pm 3$ months $(95 \%$ C.I. $=57$ 68 months) in group A, $53 \pm 3$ months (95\% C.I. $=47-59$ months) in group B and $37 \pm 3$ months (95\% C.I. $=31-44$ months) in group C. Statistically significant differences were observed between the survival rates of these three groups of patients over time $(\mathrm{p}=0.003, \log$-rank test), with group $\mathrm{C}$ having worse prognosis than group $\mathrm{A}(\mathrm{p}=0.002)$ and group $B(p=0.035)$; the difference between the groups A and B did not reach the statistical significance $(\mathrm{p}=0.168)$ (Figure 1$)$. During follow-up, mortality rate was $10.8 \%, 16.2 \%$ and $36.8 \%$ for groups A, B and C, respectively $(\mathrm{p}=0.002)$. Cox regression analysis revealed that patients of group $\mathrm{C}$ were 5 times $(\mathrm{HR}=5.08,95 \% \mathrm{CI}=1.53-9.73, \mathrm{p}=0.005)$ and almost 3 times $(\mathrm{HR}=2.78,95 \% \mathrm{CI}=1.06-7.26, \mathrm{p}=0.037)$ more likely to die of cancer than patients of groups A and B, respectively; an almost two-fold increased risk of death was observed in patients of group B compared to patients of group A $(\mathrm{HR}=1.87,95 \% \mathrm{CI}=0.52-6.66, \mathrm{p}=0.335)$.

Investigation with multivariate Cox proportional hazards regression analysis revealed that positive lymph node status (adjusted Hazard ratio $(\mathrm{aHR})=3.12$, 95\% C.I. $=1.18-8.32, \mathrm{p}=0.022)$, immunohistochemical c-erbB2 overexpression $(\mathrm{aHR}=4.54$, $95 \%$ C.I. $=1.37-15.10, \mathrm{p}=0.014)$ and the simultaneous presence of the two cytokines $(\mathrm{aHR}=4.45,95 \%$ C.I. $=1.07-18.61$, $\mathrm{p}=0.040$ compared to group $\mathrm{A}$; $\mathrm{aHR}=3.63,95 \%$ C.I. $=1.20$ $11.06, \mathrm{p}=0.023$ compared to group B) remained independent determinants for poor survival.

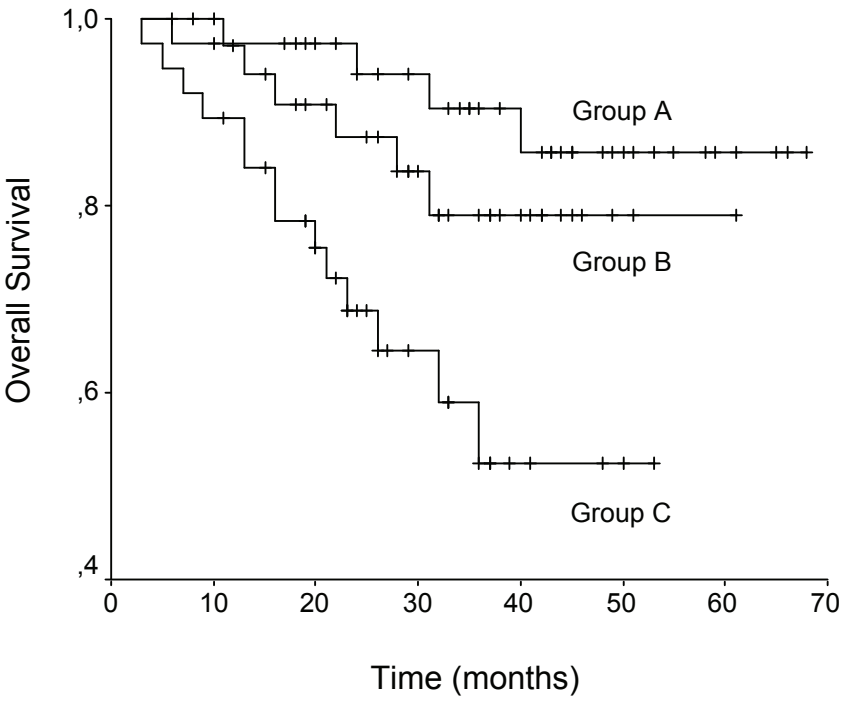

Figure 1. Overall survival of breast cancer patients according to the coexpression of IL-6 and TNF-a (Group A: patients with both IL-6 and TNF-a low; Group B: patients with IL-6 or TNF-a high; Group C: patients with both IL- 6 and TNF-a high). Log-rank test: $p=0.168$ (Group A vs Group B); $\mathrm{p}=\mathbf{0 . 0 0 2}$ (Group A vs Group C); p=0.035 (Group B vs Group C).

\section{Discussion}

Although cytokines were initially discovered as secreted proteins that mediate and regulate immunity and inflammation processes, it is becoming clear that their functions extend to many other aspects of biology, including breast cancer $[27,28]$. IL-6 and TNF-a are perhaps the best characterised tumorigenic cytokines involved not only to initiation but in all stages of tumor development, including promotion, progression and metastasis [29-32]. In the present study, the prognostic value of the coexpression pattern of serum IL-6 and TNF- $\alpha$ was examined by correlating them to the traditional surgical pathologic prognostic factors and the survival rate of breast cancer patients. We demonstrated that: (A) high levels of each of the two cytokines alone were independently associated with higher likelihood for the presence of more than three positive lymph nodes with adjusted odds ratios of 4.2 for IL- 6 and and 3.8 for TNF- $\alpha$; (B) the coexpression of high levels of the two cytokines was also independently associated with the extension of the disease with adjusted odds ratios of 7.8 for the presence of more than three positive lymph nodes and 14.1 for lymphovascular invasion; (C) there was a positive association between the expression of the two cytokines, probably indicating that their role in the tumorigenic activity may share a common molecular pathway; (D) patients with both cytokines high, had significantly shorter survival and higher risk of death compared to patients with both cytokines low (adjusted Hazard ratio [aHR], 4.45) and patients with only one of the cytokines high (aHR 3.63). Our results indicate that the combined expression of these two cytokines appears 
to be a useful independent prognostic marker for breast cancer outcome.

Several studies have elaborated on the independent negative impact on prognosis of high levels of IL- 6 or TNF- $\alpha$ in serum of patients with breast cancer [16,33]. Recently, Al-Hassan et al. [34] also found elevated serum IL-6 and TNF- $\alpha$ levels in higher stages among newly diagnosed breast cancer patients, Alsuhail [35] associated higher serum levels of these cytokines with higher stages and distant metastasis in Iraqi breast cancer patients, while Ravishankaran and Karunanithi [36] associated higher serum levels of IL- 6 with tumor invasion, the presence of distant metastasis and overall survival in Indian breast cancer patients. The present results, regarding to each cytokine separetaly, are also in keeping with the preliminary results published by our group, using a smaller sample of breast cancer patients, where it was shown that the quantitative expression of the serum levels of IL-6 [23] and TNF-a [24] were independent prognostic factors for extended lymph node $(>3)$ involvement and shorter survival. Although these studies suggest that elevated levels of the two cytokines may contribute to disease progression, a clear cut conclusion in this issue has not yet been reached; serum levels of IL- 6 and TNF- $\alpha$ were found to increase with the advancement of the disease stages in breast cancer, but these differences were not statistically significant [37], whereas no statistically significant association of IL-6 and TNF- $\alpha$ was found with the presence of distant metastasis in patients with esophageal cancer [38]. A major finding of this multiple marker investigation was that the coexpression of high serum IL-6 and TNF-a levels enhanced the predictive value of the number of positive lymph nodes and lymphovascular invasion. Moreover, regardless other well-established prognostic factors, the combined analysis of IL- 6 and TNF- $\alpha$ gave additional prognostic information regarding survival compared to serum IL- 6 or TNF- $\alpha$ alone. In particular, the simultaneous presence of high IL- 6 and TNF- $\alpha$ levels defined a high-risk subgroup of patients, which were independently associated with worse survival not only compared to patients with both cytokines low, but also compared to patients with only one of the two cytokines high. Our findings demonstrate that the simultaneous presence of IL- 6 and TNF- $\alpha$ contributes on the progression and dissemination of breast cancer.

TNF-a and IL-6 seem to play an important role in tumor formation, invasion, and metastasis due to their ability to activate a variety of oncogenic transcription factors, such as Nuclear Factor-kappa B (NF- $\mathrm{kB})$, protein-1 (AP-1) and Signal Transducer and Activator of Transcription (STATs 1, 3 and 5) [39-42]. Abnormal activation of NF- $\mathrm{kB}$ and/or STATs is found in over $50 \%$ of all cancers, which can induce many biological changes within the affected cell, such as resistance to apoptosis, increase of proliferation, differentiation, angiogenesis, and immune modulation in the cells, thereby increasing tumor growth [30,43-47]. so renders cancer cells resistant to apoptosis and speeds up their rate of proliferation, Autocrine and/or paracrine mechanisms might lead to NF- $\mathrm{KB}$ and STAT3 activation in cancer, since activating mutations in the genes encoding these transcription factors are rare. Cytokines not only are involved in the activation mechanisms through which they act, but they are considered to form a cytokine network, either autocrine or paracrine, acting in an amplifying cascade, to be involved in the system of invasion and metastasis through receptors expressed on cancer cells. Another major finding of the present study was the positive association between the expression of the two cytokines. Our finding is consistent with the reports which demonstrate that IL- 6 and TNF-a were interdependent cytokines [48-50]. Ben-Baruch [51], in a review of breast cancer development and progression, indicated the fact that the IL- 6 and TNF- $a$ are interrelated and may act in an additive manner, suggesting that these cytokines, together with IL-1, form a network of related factors that may affect tumor cell progression in a cooperative manner. A clear positive correlation between IL- 6 and TNF- $\alpha$ levels, which may explain the role of these two cytokines in tumor growth, was also found by Alsuhail [35], who claimed that the often inaccurate predication of survival in patients with metastasic breast cancer, may be indicated by biological parameters, such as IL- 6 and TNF- $\alpha$.

In conclusion, the present study showed that the coexpression of high IL- 6 and TNF-a levels correlates significantly with classical clinicopathological parameters indicative of a more aggressive behaviour of this carcinoma and most importantly, it correlates with reduced survival rate of breast cancer patients. It also provided evidence that IL- 6 and TNF-a are interdependent cytokines, reinforcing the separate negative impact of each one of these two cytokines on cancer progression and survival. Our findings suggest that the coexpression of the two cytokines has strong prognostic value for breast cancer outcome and merits to be an independent biomarker of clinical use.

\section{References}

[1] ELSTON CW, ELLIS IO, PINDER SE Pathological prognostic factors in breast cancer. Crit Rev Oncol Haematol 1999; 31: 209-223. http://dx.doi.org/10.1016/S1040-8428(99)00034-7

[2] ISAACS C, STEARNS V, HAYES DF New prognostic factors for breast cancer. Semin Oncol 2001; 28: 53-67. http://dx.doi. org/10.1016/S0093-7754(01)90045-4

[3] DUFFY MJ Urokinase plasminogen activator and its inhibitor, PAI-1, as prognos-tic markers in breast cancer: from pilot to level 1 evidence studies. Clin Chem 2002; 48: 1194-1197.

[4] BOSL GJ, MOTZER RJ Testicular germ-cell cancer. N Engl J Med 1977; 337: 242-251. http://dx.doi.org/10.1056/ NEJM199707243370406

[5] FISHER PM, HANCOCK BW Gestational trophoblastic disease and their treat-ment. Cancer Treat Rev 1997; 23: 1-16. http://dx.doi.org/10.1016/S0305-7372(97)90017-7

[6] RUSTIN GJS Use of CA 125 to assess response to new agents in ovarian cancer trials, J Clin Oncol 2003; 21(10 Suppl): $187 \mathrm{~s}-193 \mathrm{~s}$.

[7] DUFFY MJ Carcinoembryonic antigen as a marker for colorectal cancer: is it clin-ically useful? Clin Chem 2001; 47: 624-630. 
[8] PARKER C Active surveillance: towards a new paradigm in the management of early prostate cancer. Lancet Oncol 2004; 5: 101-106. http://dx.doi.org/10.1016/S1470-2045(04)01384-1

[9] DUFFY MJ Serum tumor markers in breast cancer: are they of clinical value? Clinical Chemistry 2006; 52(3): 345-351. http://dx.doi.org/10.1373/clinchem.2005.059832

[10] PAPADOPOULOU E, TRIPSIANIS G, ANAGNOSTOPOULOS K, TENTES I, KAKOLYRIS S et al. The influence of serum HER-2 levels and HER-2 codon 655 polymorphism on breast cancer outcome. Neoplasma 2008; 55: 113-121.

[11] EBELING FG, STIEBER P, UNTCH M, NAGEL D, KONECNY GE et al. Se-rum CEA and CA 15-3 as prognostic factors in primary breast cancer. Br J Cancer 2002; 22: 1217-1222. http://dx.doi.org/10.1038/sj.bjc.6600248

[12] MOLINA R, FILELLA X, ALICARTE J, ZANON G, PAHISA $J$ et al. Prospec-tive evaluation of CEA and CA 15.3 in patients with locoregional breast cancer. Anti-cancer Res 2003; 23: 1035-1042.

[13] CARNEY WP, NEUMAN R, LIPTON A, PRICE C Potential clinical utility of serum HER-2/neu oncoprotein concentrations in patients with breast cancer. Clin Chem 2003; 49: 1579-1598. http://dx.doi.org/10.1373/49.10.1579

[14] KNUPFER H, PREISS R Significance of interleukin-6 (IL6) in breast cancer (review). Breast Cancer Res Treat 2007; 102:129-135. http://dx.doi.org/10.1007/s10549-006-9328-3

[15] CHAVEY C, BIBEAU F, GOURGOU-BOURGADE S, BURLINCHON S, BOISSIERE F et al. Oestrogen receptor negative breast cancers exhibit high cytokine content. Breast Cancer Res 2007; 9: R15. http://dx.doi.org/10.1186/bcr1648

[16] NICOLINI A, CARPI A, ROSSI G Cytokines in breast cancer. Cytokine Growth Factor Rev 2006; 17: 325-337. http://dx.doi. org/10.1016/j.cytogfr.2006.07.002

[17] KINDER M, CHISLOCK E, BUSSARD K, SHUMAN L, MASTRO A Metas-tatic breast cancer induces an osteoblast inflammatory response. Exp Cell Res 2008; 314: 173-183. http://dx.doi.org/10.1016/j.yexcr.2007.09.021

[18] SALGADO R, JUNIUS S, BENOY I, VAN DAM P, VERMEULEN $P$ et al. Cir-culating interleukin-6 predicts survival in patients with metastatic breast cancer. Int J Cancer 2003; 103: 642-646. http://dx.doi.org/10.1002/ijc.10833

[19] LOCKSLEY RM, KILLEEN N, LENARDO MJ The TNF and TNF receptor su-perfamilies: integrating mammalian biology. Cell 2001; 104: 487-501. http://dx.doi.org/10.1016/S00928674(01)00237-9

[20] MACEWAN DJ TNF receptor subtype signalling: differences and cellular con-sequences. Cell Signal 2002; 14: 477-492. http://dx.doi.org/10.1016/S0898-6568(01)00262-5

[21] BALKWILL F Tumor necrosis factor or tumor promoting factor? Cytokine Growth Factor Rev 2002; 13: 135-141. http://dx.doi.org/10.1016/S1359-6101(01)00020-X

[22] VILCEK J, LEE TH Tumor necrosis factor. New insights into the molecular mechanisms of its multiple actions. J Biol Chem 1991; 266: 7313-7316.

[23] TRIPSIANIS G, PAPADOPOULOU E, BOTAITIS S, ANAGNOSTOPOULOS K, TENTES I et al. Diagnostic and prognostic significance of serum IL-6 levels in breast cancer. JP Journal of Biostatistics 2012; 1-2: 59-77.
[24] PAPADOPOULOU E, TRIPSIANIS G, ANAGNOSTOPOULOS K, TENTES I, KAKOLYRIS S et al. Significance of serum tumor necrosis factor-alpha and its inter-action with HER-2 codon 655 polymorphism on breast cancer outcome. Int J Biol Markers 2010; 25: 126-135.

[25] BLOOM HJG, RICHARDSON WW Histological grading and prognosis in breast cancer. Br J Cancer 1957; 11: 359-377. http://dx.doi.org/10.1038/bjc.1957.43

[26] UNION INTERNATIONALE CONTRE LE CANCER (UICC). TNM classifica-tion of malignant tumors (4th ed). Berlin: Springer Verlag, 1992.

[27] LIN WW, KARIN M A cytokine-mediated link between innate immunity, in-flammation, and cancer. J Clin Invest 2007; 117: 1175-1183. http://dx.doi.org/10.1172/JCI31537

[28] THOMSON AW, LOTZE MT The cytokine handbook (4th ed). London: Aca-demic Press, 2003.

[29] GRIVENNIKOV SI, GRETEN FR, KARIN M Immunity, inflammation, and cancer. Cell 2010; 140: 883-899. http://dx.doi. org/10.1016/j.cell.2010.01.025

[30] GRIVENNIKOV SI, KARIN M Dangerous liaisons: STAT3 and NF-kappaB collaboration and crosstalk in cancer. Cytokine Growth Factor Rev 2010; 21: 11-19. http://dx.doi. org/10.1016/j.cytogfr.2009.11.005

[31] AGGARWAL BB, VIJAYALEKSHMI RV, SUNG B Targeting infl ammatory pathways for prevention and therapy of cancer: short-term friend, long-term foe. Clin Cancer Res 2009; 15: 425-430. http://dx.doi.org/10.1158/1078-0432.CCR-08-0149

[32] GRIVENNIKOV SI, KARIN M Inflammatory cytokines in cancer: tumor necro-sis factor and interleukin 6 take the stage. Ann Rheum Dis 2011; 70(Suppl 1): i104-i108. http://dx.doi. org/10.1136/ard.2010.140145

[33] RAO VSR, DYER CE, JAMEEL JKA, DREW PJ, GREENMAN J Potential prognostic and therapeutic roles for cytokines in breast cancer (Review). Oncology Reports 2006; 15: 179-185.

[34] AL-HASSAN AA, AL-GHURABI BH, AL-KARKHI IH Prognostic value of proinflammatory cytokines in breast cancer. J Biomol Res Ther 2012; 1:104.

[35] ALSUHAIL R Serum level of interleukin 6 and tumor necrosis factor in Iraqi breast cancer patients. MMJ 2008; 7: 34-36.

[36] RAVISHANKARAN P, KARUNANITHI R Clinical significance of preopera-tive serum interleukin-6 and C-reactive protein level in breast cancer patients. World J Surg Oncol 2011; 9: 18. http://dx.doi.org/10.1186/1477-7819-9-18

[37] ALI HQ, MAHDI NK, and AL-JOWHER MH Serum ig and cytokine levels in women with breast cancer before and after mastectomy. Medical Journal of Islamic World Academy of Sciences 2012; 20: 121-129.

[38] AYDIN Y, KAPLAN I, BILEN Y, BULUT C, GENÇ F et al. Plasma levels of IL- 6 and TNF- $\alpha$ in patients with esophageal cancer. Turk J Med Sci 2012; 42: 762-767.

[39] MOORE RJ, OWENS DM, STAMP G, ARNOTT C, BURKE $F$ et al. Mice defi-cient in tumor necrosis factor-alpha are resistant to skin carcinogenesis. Nat Med 1999; 5: 828-831. http://dx.doi.org/10.1038/10552

[40] BALKWILL F Tumor necrosis factor or tumor promoting factor? Cytokine Growth Factor Rev 2002; 13: 135-141. http://dx.doi.org/10.1016/S1359-6101(01)00020-X 
[41] BALKWILL F Tumor necrosis factor and cancer. Nat Rev Cancer 2009; 9: 361-371. http://dx.doi.org/10.1038/ $\underline{\operatorname{nrc} 2628}$

[42] BROMBERG JF, WRZESZCZYNSKA MH, DEVGAN G, ZHAO Y, PESTELL RG et al. Stat3 as an oncogene. Cell 1999; 98: 295-303. http://dx.doi.org/10.1016/S0092-8674(00)81959$\underline{5}$

[43] ARA T., DECLERCK Y Interleukin-6 in bone metastasis and cancer progres-sion. Eur J Cancer 2010; 46: 1223-1231. http://dx.doi.org/10.1016/j.ejca.2010.02.026

[44] LIU Y, FUCHS J, LI CH, LIN J IL-6, a risk factor for hepatocellular carcinoma. FLLL32 inhibits IL-6-induced STAT3 phosphorylation in human hepatocellular can-cer cells, Cell Cycle 2010; 9: 3423-3427. http://dx.doi.org/10.4161/ cc.9.17.12946

[45] YU H, PARDOLL D, JOVE R. STATs in cancer inflammation and immunity: a leading role for STAT3. Nat Rev Cancer 2009; 9: 798-809. http://dx.doi.org/10.1038/nrc2734

[46] BOLLRATH J, GRETEN FR IKK/NF-kappaB and STAT3 pathways: central signalling hubs in inflammation-mediated tumor promotion and metastasis. EMBO Rep 2009; 10: 1314-1319. http://dx.doi.org/10.1038/embor.2009.243
[47] KIM SY, KANG JW, SONG X, KIM BK, YOO YD et al. Role of the IL-6-JAK1-STAT3-Oct-4 pathway in the conversion of nonstem cancer cells into cancer stem-like cells, Cell Signal 2013; 25: 961-969. http://dx.doi.org/10.1016/j.cellsig.2013.01.007

[48] ALVAREZ B, QUINN LS, BUSQUETS S, QUILES MT, LOPEZ-SORIANO FJ et al. Tumor necrosis factor-alpha exerts interleukin-6-dependent and independent ef-fects on cultured skeletal muscle cells. Biochim Biophys Acta 2002; 1542(1-3): 66-72. http://dx.doi.org/10.1016/S0167-4889(01)00167-7

[49] SHARMA R, ANKER SD Cytokines, apoptosis and cachexia: the potential for TNF antagonism. Int J Cardiol 2002; 85: 161-171. http://dx.doi.org/10.1016/S0167-5273(02)00244-9

[50] KAYACAN O, KARNAK D, BEDER S, GÜLLÜ E, TUTKAK $\mathrm{H}$ et al. Impact of TNF-alpha and IL-6 levels on development of cachexia in newly diagnosed NSCLC patients. Am J Clin Oncol 2006; 29: 328-335. http://dx.doi.org/10.1097/01. coc.0000221300.72657.e0

[51] BEN-BARUCH A Host microenvironment in breast cancer development: In-flammatory cells, cytokines and chemokines in breast cancer progression: reciprocal tumor-microenvironment interactions. Breast Cancer Res 2003; 5: 31-36. http://dx.doi.org/10.1186/bcr690 